\title{
A European Society of Breast Cancer Specialists (EUSOMA) elöírásainak megfelelő emlőrákellátás minőségbiztosítási elemzése az Országos Onkológiai Intézetben
}

\author{
Újhelyi Mihály dr. ${ }^{1}$ - Pukancsik Dávid dr. ${ }^{1}$ - Kelemen Péter dr. ${ }^{1}$ \\ Sávolt Ákos dr. ${ }^{1}$ - Gődény Mária dr. ${ }^{2}$ - Kovács Eszter dr. ${ }^{2}$ \\ Udvarhelyi Nóra dr. ${ }^{3}$ - Bak Mihály dr. ${ }^{4}$ - Polgár Csaba dr. ${ }^{5}$ \\ Rubovszky Gábor dr. ${ }^{6}$ - Kásler Miklós dr. ${ }^{7}$ - Mátrai Zoltán dr. ${ }^{1}$ \\ Országos Onkológiai Intézet, ${ }^{1}$ Emlő- és Lágyrészsebészeti Osztály, \\ ${ }^{2}$ Onkológiai Képalkotó és Invazív Diagnosztikai Központ, ${ }^{3}$ Sebészi és Molekuláris Daganatpatológiai Centrum, \\ ${ }^{4}$ Citopatológiai Osztály, ${ }^{5}$ Sugárterápiás Központ, \\ ${ }^{6}$, B” Belgyógyászati-Onkológiai és Klinikai Farmakológiai Osztály, Budapest \\ ${ }^{7}$ Országos Onkológiai Intézet, Budapest
}

\begin{abstract}
Bevezetés: A European Society of Breast Cancer Specialists létrehozta az emlőrákellátást végző onkológiai központok és szakorvosok európai minőségbiztosítási feltételrendszerét, hogy egységes minimumstandardok bevezetésével csökkentse az emlőrák mortalitását a kontinensen. Célkitüzés: Jelen vizsgálat célja, hogy az Országos Onkológiai Intézet Emlő- és Lágyrészsebészeti Osztályán operált, illetve az intézetben multidiszciplinárisan kezelt emlődaganatok komplex onkológiai ellátását a European Society of Breast Cancer Specialists minőségbiztosítási kívánalmai szerint elemezze és a nagy esetszámú, reprezentatív minta révén a magyar emlőrákos populációról részletes klinikopatológiai adatokat szolgáltasson az onkológiai ellátórendszer számára. Módszer: 2011. június 1. és 2012. május 31. között multidiszciplinárisan kezelt emlődaganatok részletes klinikopatológiai retrospektív adatfeldolgozását végezték a European Society of Breast Cancer Specialists egységes nemzetközi kritériumrendszere szerint. Eredmények: A vizsgált időszakban 906 betegnél történt malignus, illetve jóindulatú emlődaganat miatt műtét. Az EUSOMA kötelező minőségbiztosítási minimumelvárásainak az Országos Onkológiai Intézet eredményei mindenben megfeleltek. Következtetések: Az Országos Onkológiai Intézet emlődiagnosztikával és multidiszciplináris onkológiai kezelésével foglalkozó emlőrák-ellátási szervezeti egysége a European Society of Breast Cancer Specialists által meghatározott minimumesetszámot, személyi és tárgyi feltételeket teljesíti. Orv. Hetil., 2016, 157(42), 1674-1682.
\end{abstract}

Kulcsszavak: emlőrák, minőségbiztosítás, epidemiológia

Breast cancer care quality analysis of the National Institute of Oncology in Hungary according to the requirements of European Society of Breast Cancer Specialists (EUSOMA)

Introduction: The European Society of Breast Cancer Specialists has created quality indicators for breast units to establish minimum standards and to ensure specialist multimodality care with the conscious aim of improving outcomes and decreasing breast cancer mortality. Aim: The aim of this study was to analyse the breast cancer care in the National Institute of Oncology according to the European Society of Breast Cancer Specialists requirements and in a large number of cases in order to present representative clinico-pathological data on the incidence of breast cancer in Hungary. Method: According to the European Society of Breast Cancer Specialists uniformed criteria clinicopathological data of multimodality treated breast cancer cases were retrospectively analysed between June 1, 2011 and May 31, 2012. Results: During the period of interest 906 patients underwent breast surgery for malignant or 
benign lesions. According to the European Society of Breast Cancer Specialists quality indicators the breast cancer care of the National Institute of Oncology is eligible. Conclusions: The diagnostic modalities and multimodality care of breast cancer of the National Institute of Oncology breast unit meets the critical mass and minimum standards of the European Society of Breast Cancer Specialists criteria.

Keywords: breast neoplasm, quality control, epidemiology

Újhelyi, M., Pukancsik, D., Kelemen, P., Sávolt, Á., Gödény, M., Kovács, E., Udvarbelyi, N., Bak, M., Polgár, Cs., Rubovszky, G., Kásler, M., Mátrai, Z. [Breast cancer care quality analysis of the National Institute of Oncology in Hungary according to the requirements of European Society of Breast Cancer Specialists (EUSOMA)]. Orv. Hetil., 2016, 157(42), 1674-1682.

(Beérkezett: 2016. július 7.; elfogadva: 2016. augusztus 7.)

\section{Rövidítések}

$\mathrm{A}+\mathrm{TAX}=$ doxorubicin és paclitaxel; $\mathrm{AC}=$ doxorubicin, cyclophosphamid; ADM-TXT = doxorubicin, docetaxel; BU = (breast unit) emloccentrum; $\mathrm{CMF}=$ cyclophosphamid, methotrexat, fluorouracil; DCIS = in situ ductalis carcinoma; EBCC = European Breast Cancer Conference; EORTC-BCCG $=$ European Organization for the Research and Treatment of Cancer Breast Cancer Cooperative Group; EPI = epirubicin, cyclophosphamid; EPI-TXT = epirubicin, docetaxel; ER = ösztrogénreceptor; ESMO = European Society of Medical Oncology; EUSOMA = European Society of Breast Cancer Specialists; FAC $=5$-fluorouracil, doxorubicin, cyclophosphamid; FEC = 5-fluorouracil, epirubicin, cyclophosphamid; FISH = fluorescent in situ hybridization; HER2 = humán epidermalis növekedési faktor 2-es típusú receptor; $\mathrm{MB}=$ multidiszciplináris emlőterápiás bizottság; OOI = Országos Onkológiai Intézet; $\mathrm{PR}=$ progeszteronreceptor; $\mathrm{ROLL}$ = radio-guided occult lesion localization

Magyarországon évente közel 7400 új emlőrákos megbetegedést diagnosztizálnak és több mint 2000 nő hal bele a betegségbe. Az emlörák incidenciája Európában lassan, de emelkedik. Az északi országokban előfordulása gyakoribb, mint a déli államokban [1]. A EUROCARE-3 és EUROCARE-4 vizsgálatok Európában a földrajzi elhelyezkedés alapján különbséget találtak az emlórákkal kapcsolatos túlélésben. A legjobb túlélési statisztikákat a skandináv országokban (kivéve Dánia) és Közép-Európában, kissé rosszabb statisztikai eredményeket a déli országokban, alacsonyabb túlélési statisztikákat az Egyesült Királyságban és Írországban, végül a legrosszabb túlélési eredményeket Kelet-Európában találták $[1,2]$. Az említett vizsgálatok rámutattak arra, hogy a hasonló gazdasági helyzetú és egészségügyi rendszerrel rendelkező országok esetében is észlelhetó érdemi különbség a mortalitási statisztikákban. A különbségek okaiként az eltérő diagnosztikus és terápiás protokollokat nevezték meg [2]. Az ellátásban tapasztalható egyenlőtlenségek miatt szükségessé vált a multidiszciplináris emlőterápiás szervezeti egységek, az úgynevezett „breast unitok” (BU) kialakítása, amelyek egységes diagnosztikus és terápiás rendszert alkalmazva érik el az emlőrákos halálozás csökkenését. Először 1998-ban fogalmazódott meg a multidiszciplináris emlőterápiás szervezeti egység fogalma Firenzében az első Európai Emlőrák Konferencián (European Breast Cancer Conference - EBCC). A konferenciát együttesen a „European Organization for the Research and Treatment of Cancer Breast Cancer Cooperative Group” (EORTC-BCCG), a „European Society of Mastology” (EUSOMA) és a „Europa Donna” szervezte. A delegált képviselők az emlőrákkal kapcsolatos kutatások, genetikai prediszpozíció, pszichoszociális státusz, kezelés és ápolás alapján létrehozták a „Firenzei Nyilatkozatot" (The Florence Statement). A nyilatkozat részletesen ismerteti az emlőrákkal foglalkozó központok egységes, kötelező érvényű minőségbiztosítási feltételrendszerét [3]. Egyúttal az EORTC és az EUSOMA által alapított munkacsoport megalkotta az emlőrák gyógyításával foglalkozó szakorvosokkal szemben támasztott alapkövetelményeket [4].

Az említett vezérfonalak nagy hatással voltak az európai multidiszciplináris centrumok létrehozására. Kiemelt fontosságú volt az akkreditációs feltételrendszer létrehozása, amely a második Európai Emlőrák Konferencián a „Brüsszeli Nyilatkozatban” (The Brussels Statement) került összefoglalásra [5]. A negyedik Európai Emlőrák Konferencián megalkották a „Hamburgi Nyilatkozatot” (The Hamburg Statement), amely kiemelten hangsúlyozta az egységes minimumkövetelményeknek megfelelő multidiszciplináris emlőterápiás szervezeti egységek szükségességét. A felsorolt nyilatkozatok hatására az Európai Parlament 2003-ban állásfoglalást adott ki [6], amelyben egyértelmúen támogatta a minősített BU-k intézményrendszerét.

Az EUSOMA-akkreditált BU minősítés követelménye, hogy az adott centrumban a multidiszciplináris emlőterápiás bizottsági $(\mathrm{MB})$ döntést követôen évente legalább 150 újonnan diagnosztizált emlőrákos beteg komplex onkológiai kezelése történjen. Az emlőterápiás szervezeti egység munkáját egy felelős vezető koordinálja. A BU-nak írásos, folyamatosan frissített szakmai protokollal kell rendelkeznie, amelynek rendszeres megújítását és auditját biztosítani kell. Az EUSOMA-akkreditáció megszerzése önkéntes, amelynek elengedhetet- 
len része a standardizált adatbázis kialakítása és vezetése. Az említett egységes európai adatbázis lehetővé teszi a BU tevékenységének minőségbiztosítási értékelését, a BU-k múködésének összehasonlítását, valamint a szakemberek számára a klinikai teljesítményük tudományos igényű elemzését. A részletes adatfeldolgozás megteremti a lehetőségét egy prospektíven vezetett, folyamatosan karbantartott közös európai emlőadatbázisnak. Az akkreditált emlőcentrum további feladatai közé tartozik a lakossági mammográfiás szưrés biztosítása, valamint oktatási és egyéb tudományos kutatási tevékenységek ellátása is $[7,8]$.

Vizsgálatunk célja az volt, hogy az Országos Onkológiai Intézet (OOI) Emlő- és Lágyrészsebészeti Osztályán operált, majd az intézetben multidiszciplinárisan kezelt emlőrákos esetek és jóindulatú emlőelváltozásoknak részletes retrospektív klinikopatológiai adatfeldolgozását az EUSOMA által standardizált, prospektíven vezetett adatbázis alapján elvégezzük és ezáltal diagnosztikus és terápiás tevékenységünk minőségbiztosítási elemzését kapjuk meg. További cél volt, hogy az intézeti multidiszciplináris emlőrákellátás minőségbiztosítási paramétereit az EUSOMA-minimumkövetelményekkel összehasonlítsuk és ez alapján a szervezet „breast unit” minősítését megkezdjük. Az elemzett esetek nagy száma reprezentatív a teljes emlőrákos populációt illetően, így eredményeink egyben részletes keresztmetszeti képet adnak a magyar emlőrákos populációról is.

\section{Módszer}

A vizsgált betegek 2011. június 1. és 2012. május 31. között az OOI Emlő- és Lágyrészsebészeti Osztályán kerültek mütétre, majd az intézetben komplex onkológiai kezelésben részesültek emlőrák és kisebb esetszámmal jóindulatú emlőelváltozások miatt. A diagnózis felállítása, a multidiszciplináris kezelés és az utánkövetés a European Society of Medical Oncology (ESMO) vizsgált időszakban érvényben lévő ajánlásaival megegyező intézeti emlőrák-diagnosztikai és terápiás protokoll szerint történt [9].

Az emlő nem operatív diagnosztikus vizsgálatait és radiológiai utánkövetését az emlődiagnosztikában jártas, külön licencvizsgával rendelkező radiológusok végezték. A diagnózis felállítása a fizikális vizsgálat mellett komplex képalkotó eljárásokkal (röntgen-ultrahang mammográfia) történt. Malignitás gyanúja esetén vagy az elváltozás benignus voltának megerősítésére szövethenger (corebiopszia) vagy vékonytü-aspirációs citológiai mintavétel történt. A vizsgált időszakban a malignitás igazolására citológiai mintavétel volt az első választandó vizsgálat, core-biopsziás mintavétel csak bizonytalan citológiai diagnózis esetén, mastectomia vagy primer szisztémás kezelés indikációja esetén történt. Mágneses rezonancia vizsgálatot emlőimplantátum, invazív lobularis carcinoma, többgócúság vagy a komplex képalkotó vizsgálat és a klinikai kép ellentmondásossága esetén végeztünk [10].

Minden esetben MB-terápiás döntéshozatalt követően, kedvező emlőtumor/emlőtérfogat arány esetén, általában cT0-cTl-2 (cT $\leq 50 \mathrm{~mm})$ emlőmegtartó mütétet (döntően hagyományos széles excisio vagy quadrantectomia, a vizsgált időszakban onkoplasztikus emlőmegtartó mútét elenyésző számban történt), egyéb esetben mastectomiát végeztünk. A vizsgált időszakban bőrtakarékos, emlőbimbó-megtartó mastectomia, illetve azonnali rekonstrukció elenyésző számban történt. Klinikailag negatív hónalji nyirokcsomóstátusz esetén izotópjelölés és/vagy kék festékes jelöléssel őrszemnyirokcsomó-mintavétel volt a standard, kötelező intraoperatív imprint citológiai vagy fagyasztásos szövettani vizsgálattal. 2011/2012-ben érvényes intézeti protokollunk alapján a klinikailag, aspirációs citológiával igazolt hónalji nyirokcsomó-érintettség, továbbá intraoperatív vagy végleges patológiai őrszemnyirokcsomó-vizsgálat során áttétesnek (mikro- vagy makrometasztázis) bizonyult nyirokcsomók esetében minden esetben hónalji level IIII lymphadenectomiát (blokkdissectiót) (ALND) végeztünk. Emlőmegtartó mütét során a tapintható tumorok eltávolítása széles kimetszéssel történt minimum 10 mm-es makroszkópos ép szél kívánalommal. A nem tapintható tumorok eltávolítása preoperatív izotóp (radioguided occult lesion localization - ROLL) jelöléssel, majd intraoperatív specimen mammográfia/ultrahang kontrollja mellett történt. A specimenek kötelező érvényű egységes orientációját végeztük. Az érvényes intézeti protokoll alapján az $1 \mathrm{~mm}$-nél kisebb mikroszkópos sebészi szél esetében mind invazív, mind in situ ductalis carcinoma (DCIS) eseteiben a specimen orientálása alapján megadott irányú és mértékû patológiai pozitív sebészi szélnek megfelelően irányított reexcisiót vagy mastectomiát végeztünk [11]. Ismételten pozitív sebészi szél esetén mastectomia történt.

Az eltávolított specimen(ek) szövettani vizsgálatát patológus szakorvos végezte, továbbá minden diagnosztikus nehézséget jelentő eset szövettani osztályos bemutatásra került. A szövettani lelet tartalmazta az eltávolított tumor(ok) számát, méretét és helyzetét, az eltávolított és az áttétes nyirokcsomók számát, továbbá a legnagyobb áttét méretét (izolált tumorsejtek, mikrometasztázis 0,2 és $2 \mathrm{~mm}$ között vagy makrometasztázis $2 \mathrm{~mm}$ felett), az esetleges tokáttörést. A lelet továbbá tartalmazta a tumor szövettani típusát, az extenzív intraductalis komponenst, többgócúságot, mitózisindex és nukleáris gradus alapján meghatározott hisztológiai gradust, a reszekciós széleket tizedmilliméter pontosságig, lymphovascularis inváziót, környezeti lymphoid reakciót, nekrózis jelenlétét az invazív komponensben, Ki67 százalékos értékét és egyéb prognosztikus/prediktív paramétereket, mint például immunhisztokémiai vizsgálattal az ösztrogénreceptor (ER), progeszteronreceptor (PR) és a humán epidermalis növekedési faktor 2-es típusú receptor (HER2) státuszát. Bizonytalan HER2 státusz esetén FISH (fluo- 
rescent in situ hybridization) technikával történt a HER2-génamplifikáció meghatározása [12]. Szövettani eredmény birtokában $\mathrm{MB}$ döntött a további onkológiai kezelésekről.

A kemoterápiás kezelések a vizsgált időszakban FAC (5-fluorouracil, doxorubicin és cyclophosphamid), FEC (5-fluorouracil, epirubicin és cyclophosphamid), AC (doxorubicin, cyclophosphamid), módosított CMF (cyclophosphamid, methotrexat és fluorouracil az 1 . és 8. napon), EPI + módosított CMF (epirubicin, cyclophosphamid, methotrexat és fluorouracil az 1 . és 8 . napon), EC (epirubicin és cyclophosphamid), ADMTXT (doxorubicin és docetaxel), EPI-TXT (epirubicin és docetaxel) és A + TAX (doxorubicin és paclitaxel) terápián alapultak. Tripla negatív, HER2-pozitív vagy magasabb rizikójú HER2-negatív betegségek (14\% feletti Ki67 felett) kemoterápiás kezelés indikációját képezték. Hormonreceptor-pozitív (ösztrogén és/vagy progeszteron) betegség esetén praemenopausában tamoxifenkezelésben részesültek a betegek legalább 5 évig a sebészeti kezelést követően. A prognózist figyelembe véve ezt kiegészítette LHRH-analógok alkalmazása 2-5 éven át, amely egyenértékű a sebészeti bilateralis oophorectomiával. HER2-pozitivitás esetén pedig adjuváns trastuzumab volt a választandó kezelés kemoterápia mellett hetente egyszer, majd 3 hetente összesen egy évig [13].

A betegek sugárkezelését 3D besugárzástervezés alapján végeztük. Az adjuváns sugárterápia a mütétet követő hat-tizenkét héten belül megkezdődött. Amennyiben emlőmegtartó mútét történt, továbbá távoli áttét nem igazolódott, a betegek $25 \times 2$ Gy vagy $15 \times 2,67$ Gy dózisú teljes emlőbesugárzásban részesültek. Válogatott beteganyagon szövetközi, nagy dózisteljesítményû brachytherapiával vagy prospektív, klinikai vizsgálat keretében képvezérelt, intenzitásmodulált teleterápiával gyorsított részleges emlőbesugárzást is végeztünk. Közeli kimetszés (ép sebészi szél $<2 \mathrm{~mm}$ ), kiterjedt intraductalis komponens (EIC), illetve 50 éves kor alatt a teljes emlöre adott alapdózist követően tumorágy „boost” besugárzást is alkalmaztunk. A kiegészítő besugárzást 10-16 Gy teleterápiás (elektron vagy foton) vagy $3 \times 4,75$ Gy dózisú brachytherapiás „boost” sugárkezelés formájában adtuk.

Mastectomia után pT3-4 pN0-1mi státusz esetén 50 Gy mellkasfali sugárkezelést végeztünk. Négy vagy több nyirokcsomó érintettsége ( $\mathrm{pN} 2 \mathrm{a}, \mathrm{pN} 3 \mathrm{a}, \mathrm{pN} 3 \mathrm{~b}, \mathrm{pN} 3 \mathrm{c}$ ) esetén a betegek lokoregionális irradiációban részesültek, míg 1-3 pozitív nyirokcsomó esetén csak magas rizikójú esetekben (praemenopausa, grade 3 daganat, nyirokérbetörés) egyedi mérlegelés alapján végeztünk lokoregionális besugárzást [14].

Az adatfeldolgozás retrospektív módon történt az EUSOMA egységes nemzetközi kritériumrendszere szerint prospektíven vezetett, mintegy 119 különböző klinikopatológiai paramétert tartalmazó intézeti emlőrákadatbázisból. Az adatbázis az esetek 119 paraméterét foglalja magában, azaz összesen 107814 különböző adatot.

\section{Eredmények}

A vizsgált egyéves időszakban 906 betegnél történt primer vagy recidív malignus emlődaganat, illetve jóindulatú emlőelváltozás miatt mútét. A betegek közül 905 nő és 1 férfi volt. A betegek átlagéletkora 59 év (tartomány: 14-91 év) volt. A vizsgált esetek életkor szerinti megoszlását az 1. táblázatban ismertetjük.

A mütét indikációját képező elváltozások 456 esetben $(50,3 \%)$ a bal, 416 esetben $(45,9 \%)$ a jobb és $34(3,8 \%)$ esetben mindkét oldali emlőben helyezkedtek el. 692 esetben $(76,4 \%)$ szoliter, $89(9,8 \%)$ esetben multiplex azonos oldali, 34 esetben $(3,8 \%)$ multiplex ellenoldali, $70(7,7 \%)$ esetben metachron ellenoldali és $21(2,3 \%)$ esetben metachron azonos oldali volt a daganatok elhelyezkedése.

A betegek közül $185(20,4 \%)$ mammográfiás szürésből érkezett, míg 703 (77,6\%) szimptomatikus volt, 18nál $(2 \%)$ pedig a beutalás módja nem volt ismert.

Mammográfia 19 esetben $(2,1 \%) \mathrm{Rl}, 23$ esetben $(2,5 \%)$ R2, 80 esetben $(8,8 \%)$ R3, l esetben $(0,1 \%)$ R3/4, 306 esetben $(33,8 \%)$ R4, 421 esetben (46,5\%) R5 eredményt adott, míg 34 esetben $(3,8 \%)$ nem történt mammográfia, illetve 22 esetben $(2,4 \%)$ nem volt biztos adat a mammográfiáról.

Emlö-ultrahangvizsgálat 25 esetben $(2,7 \%)$ Ul, 33 esetben $(3,6 \%)$ U2, 78 esetben $(8,6 \%)$ U3, l esetben $(0,1 \%) \mathrm{U} 3 / 4,307$ esetben $(33,9 \%) \mathrm{U} 4,429$ esetben (47,5\%) U5 eredményt adott, míg 13 esetben $(1,4 \%)$ nem történt ultrahangvizsgálat, illetve 20 esetben $(2,2 \%)$ nem volt biztos adat az emlőultrahangról.

Vékonytü-aspirációs citológiai vizsgálat (FNAB) 225 esetben $(24,8 \%)$ nem történt, 43 esetben $(4,7 \%) \mathrm{Cl}, 27$ esetben (3\%) C2, 57 esetben (6,3\%) C3, 2 esetben $(0,2 \%) \mathrm{C} 3 / 4,156$ esetben $(17,2 \%) \mathrm{C} 4,386$ esetben $(42,5 \%)$ C5 eredményt adott, míg $12(1,3 \%)$ esetben nem volt biztos adat a vékonytü-aspirációs citológiai vizsgálatról.

1. táblázat | A vizsgált időszakban az OOI-ben komplex onkológiai kezelésben részesült betegek életkor szerinti megoszlása

\begin{tabular}{lc}
\hline Életkor (év) & Esetszám (\%) \\
\hline$<25$ & $10(1,1 \%)$ \\
$26-35$ & $49(5,4 \%)$ \\
$36-45$ & $98(10,8 \%)$ \\
$46-55$ & $162(17,9 \%)$ \\
$56-65$ & $302(33,4 \%)$ \\
$66-75$ & $185(20,4 \%)$ \\
$76-85$ & $90(9,9 \%)$ \\
$>86$ & $10(1,1 \%)$ \\
\hline Összesen & $906(100 \%)$ \\
\hline
\end{tabular}

OOI = Országos Onkológiai Intézet. 
Szövethenger-mintavétel (core-biopszia) 437 esetben $(48,3 \%)$ nem történt, 5 esetben $(0,5 \%) \mathrm{Bl}, 4$ esetben $(0,4 \%)$ B2, 5 esetben $(0,5 \%)$ B3, 20 esetben $(2,3 \%)$ B 4 , 432 esetben $(47,7 \%)$ B 5 eredményt adott, míg 3 esetben $(0,3 \%)$ nem volt biztos adat a core-biopsziás vizsgálatról.

Fizikális vizsgálat minden alkalommal történt, 307 $(33,9 \%)$ esetben nem volt tapintható elváltozás, 34 $(3,8 \%)$ esetben benignus elváltozásnak imponált, 559 $(61,7 \%)$ esetben malignitásra gyanús volt a tapintási lelet, $6(0,6 \%)$ esetben nem volt biztos adat a fizikális vizsgálat eredményéről. A klinikai tumorméret megoszlását a 2 táblázatban ismertetjük.

A mútétre kerülő elváltozások a preoperatív vizsgálatok alapján biztosan benignus daganatot mutattak 31 $(3,4 \%)$ esetben, míg a malignus vagy malignitás alapos gyanújával bíróknál cTis 40 eset $(4,4 \%)$, cTla 26 eset $(2,8 \%)$, cTlb 170 eset $(18,7 \%)$, cTlc 325 eset $(35,8 \%)$, cT2 260 eset $(28,7 \%)$, cT3 41 eset $(4,5 \%)$, cT4 5 eset $(0,5 \%)$, cT4a 1 eset $(0,1 \%)$, cT4b 3 eset $(0,3 \%)$ és cT4d 4 eset $(0,4 \%)$ volt.

Klinikai regionális nyirokcsomóstátusz tekintetében cN0 561 (61,9\%) esetben, cNl 247 (27,3\%) esetben, cN2 $17(1,9 \%)$ esetben és cNx 81 (8,9\%) esetben (beleértve a benignus elváltozásokat is) volt.

A klinikai stádium 79 esetben $(8,7 \%)$ vagy az elváltozás benignus volta, hiányos adatok, vagy recidív tumor miatt nem volt meghatározható, míg St 041 eset $(4,5 \%)$, St IA 376 eset $(41,5 \%)$, St IIA 236 eset $(26 \%)$, St IIB 115 eset $(12,7 \%)$, St IIIA 37 eset $(4,1 \%)$, St IIIB 13 eset $(1,4 \%)$, St IV 9 eset $(0,9 \%)$ volt. Az elváltozások közül $768(84,7 \%)$ eset klinikailag korai stádiumú volt (3. táblázat).

A kivizsgálást követően a betegeknek tett terápiás javaslat 819 esetben $(90,4 \%)$ primer mútét és 87 esetben $(9,6 \%)$ primer szisztémás kezelés volt. Az elvégzett primer mütéti típusok és arányuk a 4. táblázatban kerülnek ismertetésre.

Primer mútét során emlőmegtartás (leszámítva a 38 benignus esetet) 557 esetben (64\%), mastectomia 311 esetben (36\%), SLNB 560 esetben (64\%) és ALND 261 $(30 \%)$ esetben történt, a többi esetben $(6 \%)$ nem történt hónalji mütét, például DCIS/phyllodes, recidív daganatok stb. Intraoperatív specimenmammográfia 243 esetben $(26,8 \%)$ történt. Emlőmegtartó mútétkor a specimen átlagtömege $85,4 \mathrm{~g}$ (range $10-380 \mathrm{~g}$ ) volt (5. táblázat).

Második mütétre 164 esetben volt szükség (az összes mütét 18\%-a), ismételt kimetszésre 48 esetben (az emlömegtartó mütétek 8,6\%-a), mastectomiára 66 esetben (az emlőmegtartó mútétek $11,8 \%$-a) és 50 esetben ALND-re. Harmadik mütét 7 esetben történt $(0,8 \%), 1$ esetben ismételt kimetszés (az emlőmegtartó mütétek 0,3\%-a), 4 esetben mastectomia (az emlőmegtartó mütétek 1,2\%-a) és 2 esetben ALND. Összesen tehát az emlőmegtartó mütétek 13\%-ában $(11,8 \%+1,2 \%)$ komplettáló mastectomia és 8,9\%-ában $(8,6 \%+0,3 \%)$ ismételt kimetszés történt.
2. táblázat A vizsgált időszakban az OOI-ben komplex onkológiai kezelésben részesült betegek klinikai és patológiai tumorméreteinek megoszlása

\begin{tabular}{lcc}
\hline Tumorméret $(\mathrm{mm})$ & Klinikai, n (\%) & Patológiai, n (\%) \\
\hline$<5$ & $27(3 \%)$ & $55(6 \%)$ \\
$6-10$ & $185(20,4 \%)$ & $88(9,7 \%)$ \\
$11-20$ & $343(37,9 \%)$ & $291(32,1 \%)$ \\
$21-50$ & $297(32,8 \%)$ & $370(40,9 \%)$ \\
$>50$ & $50(5,5 \%)$ & $94(10,4 \%)$ \\
Hiányos adatok & $4(0,4 \%)$ & $8(0,9 \%)$ \\
\hline Összesen & $906(100 \%)$ & $906(100 \%)$ \\
\hline
\end{tabular}

n = esetszám; OOI = Országos Onkológiai Intézet.

3. táblázat A vizsgált időszakban az OOI-ben komplex onkológiai kezelésben részesült betegek klinikai és patológiai stádiumainak megoszlása (A táblázat a benignus eseteket is tartalmazza)

\begin{tabular}{|c|c|c|c|}
\hline Klinikai stádium & Esetszám & Patológiai stádium & Esetszám \\
\hline 0 & $41(4,5 \%)$ & 0 & $67(7,4 \%)$ \\
\hline \multirow[t]{2}{*}{ IA } & $376(41,5 \%)$ & IA & $256(28,2 \%)$ \\
\hline & & IB & $2(0,2 \%)$ \\
\hline IIA & $236(26 \%)$ & IIA & $202(22,3 \%)$ \\
\hline IIB & $115(12,7 \%)$ & IIB & $98(10,8 \%)$ \\
\hline IIIA & $37(4,1 \%)$ & IIIA & $65(7,2 \%)$ \\
\hline \multirow[t]{2}{*}{ IIIB } & $13(1,4 \%)$ & IIIB & $21(2,3 \%)$ \\
\hline & & IIIC & $32(3,5 \%)$ \\
\hline \multirow[t]{8}{*}{ IV } & $9(0,9 \%)$ & IV & $5(0,6 \%)$ \\
\hline & & y0 & $14(1,5 \%)$ \\
\hline & & yIA & $6(0,7 \%)$ \\
\hline & & yIIA & $10(1,1 \%)$ \\
\hline & & yIIB & $17(1,9 \%)$ \\
\hline & & yIIIA & $21(2,3 \%)$ \\
\hline & & yIIIB & $3(0,3 \%)$ \\
\hline & & yIIIC & $15(1,7 \%)$ \\
\hline \multirow[t]{2}{*}{$\begin{array}{l}\text { Nem } \\
\text { meghatározható }\end{array}$} & $79(8,7 \%)$ & $\begin{array}{l}\text { Nem } \\
\text { meghatározható }\end{array}$ & $34(3,8 \%)$ \\
\hline & & Benignus & $38(4,2 \%)$ \\
\hline Összesen & $906(100 \%)$ & Összesen & $906(100 \%)$ \\
\hline
\end{tabular}

OOI = Országos Onkológiai Intézet.

Az eltávolított daganatok patológiai mikroszkópos mérete 898 esetben $(99,1 \%)$ volt ismert. A daganatok méretének átlaga 27,4 mm (tartomány: 0-210 mm) volt. A klinikai és patológiai tumorméret összehasonlítását a 2. táblázatban részletezzük.

38 esetben $(4,2 \%)$ benignus, 69 esetben $(7,6 \%)$ in situ carcinoma, 791 esetben $(87,4 \%)$ invazív carcinoma, 2 esetben $(0,2 \%)$ nem epithelialis eredetü tumor, $3(0,3 \%)$ esetben egyéb elváltozás igazolódott és 3 esetben $(0,3 \%)$ ismeretlen volt. A benignus/malignus arány a narkózis- 
4. táblázat

A vizsgált időszakban az elvégzett primer mútéti típusok és arányuk

\begin{tabular}{|c|c|}
\hline Mütéti típus & Esetszám (\%) \\
\hline Lumpectomia & $24(2,6 \%)$ \\
\hline Izotópvezérelt (ROLL) széles kimetszés & $13(1,4 \%)$ \\
\hline Széles kimetszés & $28(3,1 \%)$ \\
\hline $\begin{array}{l}\text { Izotópvezérelt (ROLL) széles kimetszés } \\
\text { és őrszemnyirokcsomó-mintavétel (SLNB) }\end{array}$ & $217(24,0 \%)$ \\
\hline $\begin{array}{l}\text { Izotópvezérelt (ROLL) széles kimetszés és axillaris } \\
\text { blokkdissectio (ALND) }\end{array}$ & $11(1,2 \%)$ \\
\hline $\begin{array}{l}\text { Széles kimetszés és őrszemnyirokcsomó-mintavétel } \\
\text { (SLNB) }\end{array}$ & $110(12,1 \%)$ \\
\hline $\begin{array}{l}\text { Quadrantectomia és őrszemnyirokcsomó-mintavétel } \\
\text { (SLNB) }\end{array}$ & $118(13 \%)$ \\
\hline Széles kimetszés és axillaris blokkdissectio (ALND) & $30(3,3 \%)$ \\
\hline Quadrantectomia és axillaris blokkdissectio (ALND) & $37(4,1 \%)$ \\
\hline Mastectomia & $20(2,2 \%)$ \\
\hline $\begin{array}{l}\text { Mastectomia és őrszemnyirokcsomó-mintavétel } \\
\text { (SLNB) }\end{array}$ & $108(11,9 \%)$ \\
\hline Mastectomia és axillaris blokkdissectio (ALND) & $173(19,1 \%)$ \\
\hline Axillaris blokkdissectio (ALND) & $5(0,6 \%)$ \\
\hline $\begin{array}{l}\text { Bőrtakarékos mastectomia (SSM) és } \\
\text { őrszemnyirokcsomó-mintavétel (SLNB) }\end{array}$ & $7(0,8 \%)$ \\
\hline $\begin{array}{l}\text { Bőrtakarékos mastectomia (SSM) és axillaris } \\
\text { blokkdissectio (ALND) }\end{array}$ & $5(0,6 \%)$ \\
\hline Összesen & $906(100 \%)$ \\
\hline
\end{tabular}

ALND = axillary lymph node dissection; ROLL = radio-guided occult lesion localization; SLNB = sentinel lymph node biopsy; SSM = skin sparing mastectomy.

5. táblázat $\mid$ A vizsgált időszakban az elvégzett emlőmegtartó mútét során mért specimen átlagtömege

\begin{tabular}{lc}
\hline Specimen tömege $($ gramm $)$ & Esetszám (\%) \\
\hline$<20$ & $7(7,3 \%)$ \\
$20-40$ & $17(17,9 \%)$ \\
$40-60$ & $17(17,9 \%)$ \\
$60-80$ & $20(21,1 \%)$ \\
$80-100$ & $4(4,2 \%)$ \\
$100-120$ & $9(9,5 \%)$ \\
$120-140$ & $9(9,5 \%)$ \\
$140-200$ & $6(6,3 \%)$ \\
$>200$ & $6(6,3 \%)$ \\
\hline Összesen & $95 *(100 \%)$ \\
\hline
\end{tabular}

*557 emlőmegtartó műtétból 95 esetben történt meg a specimen tömegének meghatározása.

ban végzett emlőmútéteknél a vizsgált 12 hónapban legalább $4,2 \% / 94,9 \%$ volt.

A 791 invazív tumor közül $632(79,9 \%)$ invazív ductalis, $82(10,4 \%)$ invazív lobularis, $20(2,5 \%)$ kevert ducta- lis/lobularis, 24 (3\%) mucinosus, 1 (0,1\%) medullaris, 3 $(\sim 0,4 \%)$ tubularis, $4(0,5 \%)$ kevert ductalis és egyéb, 3 $(\sim 0,4 \%)$ tubulolobularis carcinoma volt, míg 4 esetben $(0,5 \%)$ emlőben jelentkező metasztázis, illetve 18 esetben $(2,3 \%)$ egyéb elváltozás igazolódott.

Az őrszemnyirokcsomó-eltávolítással járó esetek közül $(\mathrm{n}=560) 428$ eset $(76,4 \%)$ negatív, míg 132 eset $(23,6 \%)$ pozitív volt. Az eltávolított örszemnyirokcsomók átlagszáma 1,43 (tartomány: 1-7) volt. Mikrometasztázis 26 esetben volt észlelhető.

A pozitív őrszemnyirokcsomó-esetek közül 40-nél (30,3\%) az áttét csak a végleges szövettanban vált ismertté, második ülésben végzett mütétet indikálva. Ugyanez az összes elvégzett SLNB-re $(\mathrm{n}=560)$ vonatkoztatva (intraoperatív imprint citológia fals negatív aránya) 7,1\%. A 40 intraoperatívan fel nem ismert nyirokcsomóáttét közül $15(37,5 \%)$ mikrometasztázis volt, így a makrometasztázisok esetében az intraoperatívan fel nem ismert nyirokcsomóáttétek aránya 18,9\%, az összes sentinelesetre vonatkoztatva $2,7 \%$.

ALND során eltávolított nyirokcsomók átlagszáma 12,67 (range 2-33) volt. A blokkdissectiók 92,3\%-ában 10 vagy több nyirokcsomó került patológiai feldolgozásra. A patológiailag vizsgált 6654 nyirokcsomó közül $1578(23,7 \%)$ volt pozitív.

A patológiai stádium szerint 625 (72\%) esetben találtunk korai emlőrákot és 209 (24\%) esetben lokoregionálisan előrehaladott, illetve elenyésző számban ( $\leq 1 \%)$ IV. stádiumú emlőrákot. A klinikai és patológiai stádiumok összehasonlítását a 3. táblázatban mutatjuk be.

Az eltávolított daganatok ér- vagy nyirokérbetörést 266 esetben $(29,4 \%)$ mutattak, 488 esetben $(53,8 \%)$ nem mutattak, míg 83 esetben $(9,2 \%)$ nem történt ilyen irányú meghatározás, illetve 69 esetben $(7,6 \%)$ ismeretlen volt az adat.

A malignus daganatok immunhisztokémiai vizsgálatok alapján meghatározott altípusa 354 esetben (40,8\%) luminalis A-szerü, 237 esetben $(27,3 \%)$ luminalis B-szerü (HER2-), 78 esetben $(8,9 \%)$ luminalis B-szerú (HER2+), 67 esetben (7,7\%) HER2-pozitív (nonluminalis), 116 esetben $(13,4 \%)$ tripla negatív, 16 esetben $(1,8 \%)$ pedig meghatározhatatlan vagy ismeretlen volt.

A 486 malignus elváltozás miatt emlőmegtartó mútétben részesült beteg közül $449(92,5 \%)$ részesült adjuváns radioterápiában, míg 26 beteg $(5,3 \%)$ nem kapott és 11 beteg $(2,2 \%)$ nem fogadta el az adjuváns besugárzást. Emlőmegtartó mütétet és axillaris staginget követően távoli áttét hiányában 460 beteg $(94,7 \%)$ részesült posztoperatív sugárterápiában. A vizsgált időszakban a primer, illetve lokálisan vagy regionálisan kialakult recidív emlődaganat miatt 645 esetében (az összes malignus emlőfolyamat miatti mütéti kezelések 74,3\%-ában) javasoltunk adjuváns radioterápiát. Ebből 627 esetben $(97,2 \%)$ meg is történt a kezelés, és csak 18 esetben $(2,8 \%)$ utasította el a beteg a beavatkozást.

A vizsgált évben operált invazív betegcsoportból 393 esetben $(45,2 \%)$ volt indikált neoadjuváns vagy adjuváns 
A vizsgált időszakban kemoterápiás kezelésben részesült betegeknél alkalmazott tumorellenes gyógyszerkészítmények és el oszlásuk

\begin{tabular}{lc}
\hline $\begin{array}{l}\text { Az alkalmazott tumorellenes szer } \\
\text { (az EUSOMA általi felosztás alapján) }\end{array}$ & Esetszám \\
\hline AC (doxorubicin, cyclophosphamid) & 30 \\
CMF 1-8 (cyclophosphamid, methotrexat és & 5 \\
fluorouracil) & 1 \\
EPI + CMF 1-8 (epirubicin, cyclophosphamid, & \\
methotrexat és fluorouracil) & 106 \\
FAC (fluorouracil, doxorubicin és cyclophosphamid) & 19 \\
FEC (fluorouracil, epirubicin és cyclophosphamid) & 31 \\
EC (epirubicin és cyclophosphamid) & 9 \\
ADM-TXT (doxorubicin és docetaxel) & 10 \\
EPI-TXT (epirubicin és docetaxel) & 5 \\
A-TAX (doxorubicin és paclitaxel) & 129 \\
Más & 0 \\
Ismeretlen & \\
\hline
\end{tabular}

Az EUSOMA által megadott protokollok behatároltak, a táblázat a biológiai terápiákat egyelőre nem vizsgálja.

szisztémás kezelés (kemoterápia \pm biológiai terápia). A betegek közül 26-an (6,6\%) utasították vissza a megajánlott gyógyszeres kezelést (6. táblázat).

A vizsgált malignus betegcsoportban a 669 ER-pozitív eset mindegyikénél indikált az MB endokrin kezelést. A gyógyszer-adherenciával kapcsolatos információ nem áll rendelkezésre. Az emlőrákos betegek közül 151-nél
$(17,4 \%)$ történt petefészek gyógyszeres szuppresszió, míg 4 esetben a petefészkek mütéti eltávolítása történt.

Az EUSOMA BU minősítés minimumelvárásainak megfelelően eredményeinket a 7. táblázatban összesítettük.

\section{Megbeszélés}

Az emlőrák magas szintü onkológiai ellátórendszerének alapját az emlő megbetegedéseire specializált szakemberek és az ellátást biztosító, a minőségbiztosítási kívánalmaknak megfelelő intézmények biztosítják.

Az EUSOMA-akkreditált BU minősítés követelménye, hogy az adott centrumban MB-döntést követően évente legalább 150 újonnan diagnosztizált emlőrákos beteg multidiszciplináris kezelése történjen. A bizottság kötelezően részt vevő tagjai: emlősebész, radiológus, klinikai onkológus és sugárterapeuta. További ajánlott résztvevői: patológus, emlőterápiás nővér és onkopszichológus [15]. Az OOI emlőterápiás bizottsági ülésein a vizsgált időszakban a kötelező résztvevőkön felül egy onkopszichológus is részt vett a bizottsági üléseken. A vizsgált 12 hónap alatt MB-döntést követően 906 esetben történt emlő jó- vagy rosszindulatú elváltozása miatt sebészeti beavatkozás, majd multidiszciplináris kezelés és utánkövetés intézetünkben, teljesítve az EUSOMA BUakkreditációhoz szükséges minimumesetszámot.

A BU szakmai minimumelvárása alapján legalább 2, emlődiagnosztikában jártas radiológus (hazánkban licencvizsga van érvényben) végezze az emlő képalkotó vizsgálatait és diagnosztikus mintavételeit, akik munka-

7. táblázat | EUSOMA BU minősítés alapelvárásainak megfelelő indikátorok összehasonlítása az OOI eredményeivel

\begin{tabular}{|c|c|c|c|c|}
\hline Minőségi mutatók & Kötelező & Minimum & Cél & OOI \\
\hline Preoperatív C5/B5 diagnózisok aránya & K & $80 \%$ & $90 \%$ & $85,1 \%$ \\
\hline $\begin{array}{l}\text { Primer mútétet követően az eltávolított invazív tumorok prognosztikus/prediktív } \\
\text { markereinek (szövettani gradus, szövettani típus, hormonreceptor-státusz, patológiai } \\
\text { stádium és méret) meghatározási aránya }\end{array}$ & $\mathrm{K}$ & $90 \%$ & $98 \%$ & $97,9 \%$ \\
\hline $\begin{array}{l}\text { Primer mútétet követően az eltávolított noninvazív elváltozások prognosztikus/prediktív } \\
\text { markereinek (domináló szövettani struktúra, gradus) meghatározási aránya }\end{array}$ & $\mathrm{K}$ & $80 \%$ & $98 \%$ & $89,1 \%$ \\
\hline $\begin{array}{l}\text { Axillaris blokkdissectiók aránya, amely esetekben } 10 \text { vagy több nyirokcsomó patológiai } \\
\text { feldolgozása történt }\end{array}$ & K & $85 \%$ & $98 \%$ & $92,3 \%$ \\
\hline $\begin{array}{l}\text { Emlőmegtartó műtétet és axillaris staginget követően távoli áttét hiányában alkalmazott } \\
\text { posztoperatív sugárterápia aránya }\end{array}$ & $\mathrm{K}$ & $90 \%$ & $95 \%$ & $94,7 \%$ \\
\hline $\begin{array}{l}\text { Az invazív + in situ teljes tumorméretre vonatkoztatott } 3 \mathrm{~cm} \text {-nél kisebb tumorok esetében } \\
\text { elvégzett emlőmegtartó mútétek aránya }\end{array}$ & $\mathrm{K}$ & $70 \%$ & $80 \%$ & $80,9 \%$ \\
\hline $\begin{array}{l}\text { A noninvazív teljes tumorméretre vonatkoztatott } 2 \mathrm{~cm} \text {-nél kisebb tumorok esetében } \\
\text { elvégzett emlőmegtartó mútétek aránya }\end{array}$ & $\mathrm{K}$ & $70 \%$ & $80 \%$ & $100 \%$ \\
\hline Tisztán DCIS-esetek aránya, ahol nem történt axillaris blokkdissectio & $\mathrm{K}$ & $93 \%$ & $98 \%$ & $100 \%$ \\
\hline Hormonérzékeny daganatok esetén alkalmazott endokrin terápiák aránya & K & $80 \%$ & $90 \%$ & $99,8 \%$ \\
\hline $\begin{array}{l}\text { A } 2 \text { cm-nél nagyobb és/vagy nyirokcsomó-pozitív hormonnegatív daganatos } \\
\text { megbetegedések esetében alkalmazott adjuváns kemoterápiák aránya }\end{array}$ & $\mathrm{K}$ & $80 \%$ & $90 \%$ & $98,9 \%$ \\
\hline
\end{tabular}

BU = breast unit; DCIS = ductal carcinoma in situ; K = kötelező minimumfeltétel; OOI = Országos Onkológiai Intézet . 
idejük minimum 30\%-ában az emlőmegbetegedésekkel foglalkoznak. A központ emlődiagnosztikai részlegének emlőszűrő központként évente legalább 5000 mammográfiás szűrést kell végeznie. A radiológiai részlegnek megfelelő képalkotó eszközparkkal (mammográfia, UH, MR) és mintavételre alkalmas eszközökkel és gyakorlattal (aspirációs citológia, core-biopszia, steroataxiás mintavétel) kell rendelkeznie [15]. Az OOI Onkológiai Képalkotó és Invazív Radiológiai Központja a minimumkövetelményként előírt diagnosztikus eszközökkel rendelkezik, emellett emlőszűrő központként a Népegészségügyi Program keretében mammográfiás szűréseket végez. A vizsgált időszakban 3 licencvizsgával minősített emlőradiológus vett részt a centrum múködésében évi 18834 mammográfiás felvétel áttekintésével, teljesítve a BU-akkreditációhoz szükséges minimumfeltételeket.

A BU további minimumkövetelménye, hogy a centrumban legalább kettő emlősebész szakorvos, munkaidejük legalább 50\%-ában az emlőmegbetegedések sebészeti ellátásával foglalkozzon. Egy emlősebésznek évi legalább 50 primer emlődaganat mútéti ellátása mellett ismernie kell az alapvető rekonstrukciós és onkoplasztikus technikákat [15]. Az emlősebészeti részlegnek biztosítania kell az őrszemnyirokcsomó-mintavételi technikára alkalmas személyi és tárgyi feltételeket. A részleg további szakmai résztvevői között legalább egynek az emlőrekonstrukciós technikák terén megfelelő gyakorlattal rendelkező plasztikai sebésznek kell lennie. Az OOI Emlő- és Lágyrészsebészeti Osztálya rendelkezik a megfelelő tárgyi és személyi feltételekkel az őrszemnyirokcsomó-mintavételi technikák alkalmazásában, továbbá a nem tapintható elváltozások eltávolítása izotópos (ROLL) jelöléses technikával történik intézetünkben. A vizsgált időszakban 8 , emlőre specializálódott emlősebész és plasztikai sebész vett részt a centrum múködésében. Az OOI Emlő- és Lágyrészsebészeti Osztálya a mütéti szám, a személyi és tárgyi feltétek tekintetében megfelelt az EUSOMA BU-akkreditáció alapfeltételeinek.

A BU további alapkövetelménye, hogy legalább két patológus szakorvos vegyen részt a centrum munkájában, akik munkaidejük legalább 25\%-ában az emlőmegbetegedések citopatológiai és szövettani diagnosztikájával foglalkoznak. A patológiai diagnosztikának alkalmasnak kell lennie a prediktív/prognosztikus markerek meghatározására (immunhisztokémiai vizsgálatokkal mért ER, PR és HER2 szintje, szükség esetén FISHvizsgálat) [15]. A vizsgált időszakban az OOI Citopatológiai Osztálya és a Sebészi és Molekuláris Daganatpatológiai Centruma rendelkezett az elóírt tárgyi és személyi feltételekkel. A fent említett 12 hónapban 4 , emlőre specializálódott citopatológus és patológus szakorvos vett részt a centrum múködésében, teljesítve az EUSOMA BU-akkreditáció minimumfeltételeit.

A BU emlővel foglalkozó specializált munkacsoport fontos tagja a klinikai onkológus, aki munkaidejének leg- alább 40\%-ában kizárólag az emlődaganatok onkológiai kezeléseivel foglalkozik [15]. A fent említett 12 hónapban az OOI emlőterápiás munkacsoportjában 8 , klinikai onkológus szakvizsgával rendelkező orvos vett részt az emlődaganatok multidiszciplináris kezelésében, teljesítve a BU-hoz szükséges minimumfeltételeket.

A BU további alapkövetelménye, hogy legalább egy sugárterapeuta szakorvos vegyen részt a centrum munkájában, aki munkaidejének legalább 30\%-ában az emlődaganatok sugárkezelésével foglalkozik. A sugárterápiás részlegnek rendelkeznie kell minimum 2 megavoltos besugárzóval, CT-szimulátorral és CT-re alapozott 3 dimenziós konformális besugárzástervezésre alkalmas felszereléssel [15]. A vizsgált időszakban az OOI Sugárterápiás Központja rendelkezett az elooírt minimális tárgyi és személyi feltételekkel. A fent említett 12 hónapban legalább 10 sugárterapeuta szakorvos vett részt a centrum múködésében, teljesítve a BU-akkreditációhoz szükséges elő́rásokat.

Az EUSOMA az emlőrák multidiszciplináris szakembergárdájában egy új státuszt hozott létre, az úgynevezett emlőrák-terápiás nővérét. A BU-akkreditáció feltétele, hogy legalább kettő, speciálisan képzett emlőrák-terápiás nővér kövesse a betegek onkológiai ellátását, biztosítva a betegek pszichés támogatását, utánkövetését. Intézetünkben a vizsgált időszakban 2 emlőrák-terápiás nôvér vett részt a centrum múködésében, teljesítve a minimumszámot.

Az OOI emellett rendelkezik genetikai konzultációs és szűrési lehetőséggel, továbbá onkopszichológiai háttérrel, amelyek biztosítják az EUSOMA minőségbiztosítási kívánalmainak eleget tevő BU alapvető feltételeit [8].

Az EUSOMA BU minősítés kötelező elvárásainak megfelelően a létrehozott adatbázis alapján eredményeinket értékeltük (7. táblázat).

$\mathrm{Az}$ intézet emlőrák-ellátási gyakorlata a preoperatív egyértelmű C5/B5 diagnózisarány tekintetében az elvárt $80 \%$-os minimumot $85,1 \%$-os aránnyal elérte [8]. Primer mütétet követően az eltávolított invazív tumorok prognosztikus/prediktív markereinek (szövettani gradus, szövettani típus, hormonreceptor-státusz, patológiai stádium és méret) 97,9\%-os meghatározási aránya meghaladja az elvárt 90\%-ot és majdnem teljesíti a 98\%os célt, biztosítva a személyre szabott komplex onkológiai kezelések lehetőségét. A noninvazív elváltozások esetében a prognosztikus/prediktív markerek (domináló szövettani struktúra, gradus) meghatározási aránya adatbázisunk alapján elérte a 89,1\%-ot, amely meghaladja az elvárt 80\%-ot, teljesítve az EUSOMA BU-akkreditációhoz kötelezően elvárt minőségbiztosítási feltételeket [8].

A másik kérdéses pont az invazív és in situ teljes tumorméretre vonatkoztatott $3 \mathrm{~cm}$-nél kisebb tumoroknál elvárt minimum 70\%-os emlőmegtartás-arány, ami saját gyakorlatunkban éppen 70,3\%-ban valósult csak meg. 
Ezen adatok további finomításával 80,9\%-os arányt értünk el, teljesítve a $80 \%$-os célt. A noninvazív teljes tumorméretre vonatkoztatott $2 \mathrm{~cm}$-nél kisebb tumorok esetében elvégzett emlőmegtartó műtétek 100\%-os aránya pedig messzemenően teljesítette a $80 \%$-os célt [8].

Intézeti gyakorlatunkban az ALND-k esetében 92,3\%ban történt több mint 10 nyirokcsomó eltávolítása, teljesítve a 85\%-os kötelezően elvárt szintet, de nem érte el a 98\%-os célt. Tisztán DCIS-elváltozások esetében pedig egy esetben sem történt ALND, messze teljesítve a 98\%os célt [8].

Adjuváns terápia tekintetében emlőmegtartó műtétet és axillaris staginget (távoli áttet hiányában) követő posztoperatív sugárterápia aránya a 94,7\%-kal meghaladta a $90 \%$-os minimumszintet, gyakorlatilag elérte a $95 \%$ os célt. Hormonérzékenység alapján a hormonérzékeny daganatok esetében a posztoperatív MB az esetek 99,8\%ában indikált endokrin terápiát, amely messzemenően meghaladja a 90\%-os célt. A gyógyszer-adherenciával kapcsolatos adatok nem állnak rendelkezésünkre. A 2 cm-nél nagyobb és/vagy nyirokcsomó-pozitív, hormonnegatív daganatos megbetegedések esetében alkalmazott adjuváns kemoterápiák aránya gyakorlatunkban 98,9\%kal messzemenően teljesítette a 90\%-os célt [8].

Az OOI-ban folyó emlőrákellátás megfelel az EUSOMA BU minősítés kötelező elvárásainak mind a létrehozott adatbázis, mind a személyi és tárgyi alapkövetelmények vonatkozásában.

\section{Következtetések}

A nők leggyakoribb malignus megbetegedése és a mortalitásban tapasztalt különbségek miatt szükségessé vált a standardizált multidiszciplináris emlőterápiás szervezeti egységek létrehozása. A specializált emlőcentrumok elterjedésével, továbbá egységes diagnosztikus és terápiás protokollok alkalmazásával emelhető az onkológiai ellátás színvonala és ezzel csökkenthető az emlőrákkal kapcsolatos mortalitás.

$\mathrm{Az}$ OOI emlődiagnosztikával és multidiszciplináris onkológiai kezeléssel foglalkozó osztályai és részlegei az EUSOMA által meghatározott minimumesetszámot, személyi és tárgyi feltéteket teljesítette.

Anyagi támogatás: A közlemény megírása, illetve a kapcsolódó kutatómunka anyagi támogatásban nem részesült.

Szerzôi munkamegosztás: Ú. M., K. M., B. M., P. Cs., M. Z.: Hipotézisek kidolgozása. P. D., K. P., S. Á., K. E., U. N., M. Z.: Adatgyújtés. Ú. M., K. P., S. Á., M. Z.: Vizsgálat lefolytatása. M. Z., P. D., Ú. M.: Statisztikai elemzések. Ú. M., P. Cs., G. M., U. N., R. G., K. M., B. M., M. Z.: Kézirat megszövegezése. A cikk végleges változatát valamennyi szerző elolvasta és jóváhagyta.

Érdekeltségek: A szerzőknek nincsenek érdekeltségeik.

\section{Irodalom}

[1] Sant, M., Aareleid, T., Berrino, F., et al.: EUROCARE-3: survival of cancer patients diagnosed 1990-94 - results and commentary. Ann. Oncol. 2003, 14(Suppl. 5), v61-v118.

[2] Berrino, F., De Angelis, R., Sant, M., et al.: Survival for eight major cancers and all cancers combined for European adults diagnosed in 1995-1999: results of the EUROCARE-4 study. Lancet Oncol., 2007, 8(9), 773-783.

[3] Cataliotti, L., Costa, A., Daly, P. A., et al.: Florence statement on breast cancer, 1998: Forging the way ahead for more research on and better care in breast cancer. Eur. J. Cancer, 1999, 35(1), 14-15.

[4] The requirements of a specialist Breast Unit. Eur. J. Cancer, 2000, 36(18), 2288-2293.

[5] Piccart, M., Cataliotti, L., Buchanan, M., et al.: Brussels statement document. Eur. J. Cancer, 2001, 37(11), 1335-1337.

[6] Jassem, J., Buchanan, M., Jänicke, F., et al.: The Hamburg statement: the partnership driving the European agenda on breast cancer. Eur. J. Cancer, 2004, 40(12),1810-1811.

[7] Perry, N., Broeders, M., de Wolf, C., et al.: European guidelines for quality assurance in breast cancer screening and diagnosis. Fourth edition - summary document. Ann. Oncol., 2008, 19(4), 614-622.

[8] Wilson, A. R., Marotti, L., Bianchi, S., et al.: The requirements of a specialist Breast Centre. Eur. J. Cancer, 2013, 49(17), 35793587.

[9] Aebi, S., Davidson, T., Gruber, G., et al.: Primary breast cancer: ESMO clinical practice guidelines for diagnosis, treatment and follow-up. Ann. Oncol., 2010, 21(Suppl. 5), v9-v14.

[10] Forrai, G., Szabó, E., Ormándi, K., et al.: Imaging methods in the current diagnosis of and screening for breast cancer. [A képalkotó vizsgálómódszerek alkalmazása az emlődaganatok korszerü diagnosztikájában és szürésében.] Magy. Onkol., 2010, 54(3), 211-216. [Hungarian]

[11] Lázár, G., Besznyák, I., Boross, G., et al.: Current surgical therapy in breast cancer. [Az emlőrák korszerü sebészi kezelése.] Magy. Onkol., 2010, 54(3), 227-234. [Hungarian]

[12] Cserni, G., Francz, M., Járay, B., et al.: Pathologic diagnosis and histopathologic record of breast cancer. [Az emlörák patológiai diagnosztikája, feldolgozása és kórszövettani leletezése.] Magy. Onkol., 2010, 54(3), 217-226. [Hungarian]

[13] Láng, I., Kabán, Z, Pintér, T., et al.: Pharmaceutical therapy of breast cancer. [Az emlőrák belgyógyászati onkológiai (gyógyszeres) kezelése.] Magy. Onkol., 2010, 54(3), 237-254. [Hungarian]

[14] Polgár, C., Csejtei, A., Gábor, G., et al.: Principles of radiotherapy. [Sugárterápiás irányelvek.] Magy. Onkol., 2010, 54(3), 257265. [Hungarian]

[15] Cataliotti, L., De Wolf, C., Holland, R., et al.: Guidelines on the standards for the training of specialised health professionals dealing with breast cancer. Eur. J. Cancer, 2007, 43(4), 660-675.

(Újhelyi Mihály dr., Budapest, Ráth György u. 7-9., 1122 e-mail: ujmisi@gmail.com) 